\section{Genetic and cytological diversity in cherry tree accessions (Eugenia involucrata DC) in Rio Grande do Sul}

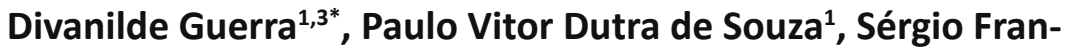 \\ cisco Schwarz ${ }^{1}$, Maria Teresa Schifino-Wittmann ${ }^{2}$, Claudio \\ André Werlang ${ }^{1}$ and Pedro Augusto Veit $^{1}$
}

\begin{abstract}
This study aimed to evaluate the genetic and cytological diversity and stability of 35 cherry tree accessions collected in Rio Grande do Sul. We used 15 RAPD (Random Amplified Polymorphic DNA) molecular markers and performed cytological analysis and number count of anthers. Analyses of genetic diversity allowed the separation of accessions into four groups, resulting in an average of 8.93 bands per primer amplified, 7.89 polymorphic bands, $88.08 \%$ of polymorphism and $86 \%$ of genetic similarity. Cytological analyses of gametic cells allowed for the characterization of accessions as diploids with $n=11$. In these, the average of meiotic cells considered normal was $82.12 \%$; average pollen viability was $92.44 \%$ and in vitro germination was $40.26 \%$; the average number of anthers was 161.85 anthers/flowers. Therefore, the accessions evaluated showed high genetic similarity and cytological stability and can be used in commercial plantations or hybridizations.
\end{abstract}

Key words: Breeding, hybridizations, molecular analysis, cytogenetic analysis.

\section{INTRODUCTION}

The Myrtaceae Family is one of the largest plant families with around 3600 species in 150 genera and is distributed in different environments throughout tropical, subtropical and temperate regions, highlighting its wide adaptive power (Landrum and Kawasaki 1997, Romagnolo and Souza 2004). In this family, the genus Eugenia is one of the most representatives since it consists of about 1000 species distributed mainly throughout Central and South America, with more than 350 native species in Brazil (Landrum and Kawasaki 1997).

The cherry tree (Eugenia involucrata DC.) is a native species of southern Brazil, belonging to the genus Eugenia and can be found from Minas Gerais to Rio Grande do Sul in forest formations of the Atlantic complex and in the forests and savannas of the Paraná basin (Donadio et al. 2004). It also occurs in Mato Grosso do Sul, Minas Gerais and Goiás and in other countries of South America (Rodrigues and Carvalho 2001). This species is commonly known as cherry tree, cerejeira-do-mato, cereja-do-rio-grande and black cherry (Lorenzi 2002) and is of great ecological importance since it is a species dispersed by animals and appropriate for the recovery of degraded areas, besides its landscape value due to the beauty of its flowers and stems (Lorenzi 2002, Carvalho 2008). The fruit have commercial potential and can be consumed fresh or processed in the
Crop Breeding and Applied Biotechnology 16: 219-225, 2016 Brazilian Society of Plant Breeding. Printed in Brazil http://dx.doi.org/10.1590/1984$70332016 v 16 n 3 a 33$

\section{*Corresponding author: \\ E-mail: divanildeguerra@yahoo.com.br}

Received: 22 December 2015 Accepted: 04 June 2016

${ }^{1}$ Universidade Federal do Rio Grande do Sul (UFRGS), Faculdade de Agronomia, Departamento de Horticultura e Silvicultura, Avenida Bento Gonçalves, 7712, 91.501-970, Porto Alegre, RS, Brazil 2 UFRGS, Faculdade de Agronomia, Departamento de Plantas Forrageiras e Agrometeorologia

${ }^{3}$ Universidade Estadual do Rio Grande do Sul (UERGS), Curso de Agronomia, Rua Cipriano Barata, 47, 98.600-000, Três Passos, RS, Brazil 
form of jams, jellies, liqueurs and juices (Oliveira 2007), in addition to the medicinal properties of the fruit and leaves (Rodrigues and Carvalho 2001).

Although having enormous potential to integrate production systems, the cherry tree is seldom used for this purpose due to lack of agronomic information, absence of improved cultivars, large need for labor to harvest the fruit (and their perishable nature), as well as having a preferential sexual system of propagation, which results in plants with high variability of agronomic traits, complicating the implementation and management of orchards (Carvalho 2008). Furthermore, the basic characteristics of the species are still unknown, so cytological analyses and technologies using molecular markers can assist in breeding programs, identifying and selecting plants with greater genetic variability and cytological stability that can be used as parents in directed crosses or in vegetative propagation (Wunch and Hormaza 2007). Thus, the aim of this study was to: a) evaluate the genetic variability of cherry tree accessions through RAPD molecular markers; b) evaluate the cytological stability of the accessions.

\section{MATERIAL AND METHODS}

Thirty-five cherry free accessions from natural populations, as well as pre-selected and cultivated populations in domestic environments were selected for the evaluation of genetic diversity and cytological analyses. The cities in the state of Rio Grande do Sul where the accessions were collected and their identification in the paper are: Venâncio Aires (1); Porto Alegre (2); Gravataí (3); Gravataí (4); Cachoeirinha (5); Porto Alegre (6); Porto Alegre (7); Porto Alegre (8); Santa Cruz do Sul (9); Charqueadas (10); Eldorado do Sul (11); Eldorado do Sul (12); Eldorado do Sul (13); Eldorado do Sul (14); Eldorado do Sul (15); Eldorado do Sul (16); Porto Alegre (17); Porto Alegre (18); Canoas (19); Canoas (20); Esteio (21); Porto Alegre (22); Estrela (23); Campina das Missões (24); Venâncio Aires (25); Guaporé (26); Santa Cruz do Sul (27); Porto Alegre (28); General Câmara (29); Eldorado do Sul (30); Três Passos (31); Bom Progresso (32); São Luiz Gonzaga (33); São Borja (34) and Tenente Portela (35).

Young leaves were collected for DNA extraction and genetic diversity evaluation through the protocol proposed by Ferreira and Grattapaglia (1998). The quantity and quality of DNA were evaluated by applying the samples to $1 \%$ agarose gel, which was stained with ethidium bromide $\left(0.5 \mathrm{ng} \mathrm{mL}^{-1}\right)$ and submitted to electrophoresis for an hour at $110 \mathrm{~V}$. The quantification was performed by comparison with $\lambda 50, \lambda 100, \lambda 200$ and $\lambda 500$ Lambdas standards and the DNA quality was evaluated by the absence of DNA traces (Guerra et al. 2016).

The genetic diversity was obtained using RAPD ("Random Amplified Polymorphic DNA") molecular markers. The reaction had a total volume of $25 \mathrm{uL}$ containing: $10 \mathrm{mM}$ of Tris- $\mathrm{HCl}, \mathrm{pH} 8.3 ; 50 \mathrm{mM}$ of $\mathrm{KCl} ; 2.0 \mathrm{mM}$ of MgCl2; $0.4 \mathrm{mM}$ of dNTPs; 0.25 uM of primer; 5.0 ng of DNA; 1 unit of Taq DNA Polymerase and ultrapure water to complete the volume. The amplification of specific regions was performed using PCR (Polymerase Chain Reaction) technique in a thermocycler, being performed for 48 cycles: $92^{\circ} \mathrm{C}$ for 30 seconds; $37^{\circ} \mathrm{C}$ for 1 minute and 30 seconds; and $72{ }^{\circ} \mathrm{C}$ for 1 minute and 30 seconds. Preceding the cycle, an initial denaturation was performed at $94{ }^{\circ} \mathrm{C}$ for 5 minutes and, afterwards, a final extension at $72{ }^{\circ} \mathrm{C}$ for 5 minutes. After the amplification, the samples were applied to agarose gel (1.8\%) and compared with the standard of known size (Gibco BRL with 100 base pairs). The time for the electrophoretic separation was of two hours at 110 volts. The gels were photographed and the fragments determined by comparison with the standard 100pb, using Kodak EDAS 290 (Electrophoresis Documentation and Analysis System) software. The results were analyzed by observing the gels and generating a binary matrix in which the individuals were genotyped in regards to the presence (1) or absence (0) of bands, creating a matrix to calculate the genetic similarity and the formation of the dendrogram using the R program (Pillar 1999). These were also evaluated in regards to the total number of amplified bands, number of bands and percentage of polymorphic bands of each primer.

For the cytological analysis, flowers were collected and fixed for 24 hours in an ethanol and acetic acid solution/ in a ratio of 3:1, and were then transferred to $70 \%$ ethanol and stored in a freezer. For the evaluations, slides were prepared with the anthers of each flower, which are macerated and stained with propionic carmine dye (2\%) (Guerra et al. 2013). For the analysis of meiotic behavior, ten flowers per accessions and at least ten meiotic cells with good chromosome spreading per slide and at all stages of meiosis were evaluated. For the estimation of pollen viability ten slides were analyzed, randomly counting 1,000 pollen grains, making a total of 10,000 grains per accession. Viability was estimated according to coloring capacity; the grains were considered viable when stained and non-viable when empty or colorless, 
and this was determined by dividing the number of stained pollen grains by the total number of grains observed and multiplying the result by 100 (Simioni and Valle 2011).

For the analysis of in vitro pollen germination, flowers at maturity stage and with closed petals were collected. The culture medium used was that described by Sahar and Spiegel-Roy (1984), with 1\% agar, 15\% sucrose, 100ppm H3BO3, $1000 \mathrm{ppm} \mathrm{Ca}(\mathrm{NO} 3) .4 \mathrm{H} 2 \mathrm{O}$, 300ppm MgSO4.7H2O and 100ppm KNO3, completing a final volume of 10ml with sterile water. The solution was heated in a microwave and afterwards a drop of culture medium in previously identified slides was added. In a laboratory the petals were removed and the anthers exposed to incandescent light; after the pollen was released it was then distributed in slides containing culture medium and a cover slip was placed on top of the medium, which were maintained in a controlled environment $\left(25^{\circ} \mathrm{C}\right)$ for 24 hours and then analyzed in an optical microscope. Four slides per population were evaluated by counting the number of randomly selected germinated and non-germinated grains in 250 pollen grains per slide, totaling 1,000 grains per accessions.

To count the number of anthers, ten flowers from each accession were selected, the petals and sepals were removed with the aid of needles and a scalpel under a magnifying glass and then separated and later counted. The results of the cytological analyses were subjected to multivariate analysis of variance (MANOVA) using SAS (SAS Institute).

\section{RESULTS AND DISCUSSIONS}

Of the 20 RAPD primers tested, 15 were selected and used for the analysis of genetic diversity of the 35 cherry tree accessions, since they were polymorphic and had good amplification profile. The fragments ranged from 200 to 1600 base pairs, with a total of 136 bands being obtained. The primers OPA-04, OPA-10 and OPN-02 produced the highest number of bands (12), whereas the OPA-03 and OPN-09 primers produced six bands. The average number of bands per primer was 8.93 and the average of polymorphic bands was 7.87 (Table 1).

The results obtained with these markers were excellent and resulted in 136 bands and $88.08 \%$ of polymorphism (Table 1). Similar values were obtained with RAPD markers by Gomes Filho et al. (2010) in guava trees (87.97\%) and by Aguiar et al. (2013), with 70 to $79 \%$ of polymorphism in Brazilian cherry tree populations. These results may be associated to the different populations evaluated as well as to the different collecting sites, because plants were sampled with considerable distance between them. Oliveira et al. (2007) reported that the expected genetic variability is distributed among populations with greater uniformity among individuals within a same population and greater variability between populations. In this evaluation, the use of 15 RAPD primers produced a total of 136 bands with an average of 8.93 fragments by primer (Table 1). Gomes Filho et al. (2010) evaluated the genetic divergence among six cultivars and

Table 1. Number of bands and percentage of polymorphism generated by 15 selected RAPD primers and used in 35 cherry accessions collected in the state of Rio Grande do Sul

\begin{tabular}{|c|c|c|c|c|c|}
\hline Primer & $\begin{array}{c}\text { Sequence } \\
\left(5^{\prime}-3^{\prime}\right)\end{array}$ & $\begin{array}{l}\text { Size } \\
\text { pb }\end{array}$ & $\begin{array}{c}\text { Total of amplified } \\
\text { bands }\end{array}$ & $\begin{array}{l}\text { Total of polymor- } \\
\text { phic bands }\end{array}$ & Polymorphism (\%) \\
\hline OPA-02 & TGCCGAGCTG & $200-1600$ & 8 & 7 & 87.50 \\
\hline OPA-03 & AGTCAGCCAC & $200-1300$ & 6 & 6 & 100.00 \\
\hline OPA-07 & GAAACGGGTG & $200-1500$ & 8 & 7 & 87.50 \\
\hline OPA-08 & GTGACGTAGG & $280-1600$ & 10 & 8 & 80.00 \\
\hline OPA-11 & ACGCGTCTGG & $250-1000$ & 7 & 6 & 85.71 \\
\hline OPA-13 & AGTCAGCCAC & $220-1600$ & 10 & 9 & 90.00 \\
\hline OPN-02 & ACCAGGGGCA & $300-1500$ & 12 & 10 & 83.33 \\
\hline OPN-04 & GACCGACCCA & $250-1600$ & 7 & 6 & 85.71 \\
\hline OPN-05 & ACTGAACGCC & $200-1500$ & 9 & 8 & 88.89 \\
\hline Mean & & & 8.93 & 7.87 & 88.08 \\
\hline
\end{tabular}


19 guava trees accessions with RAPD markers and obtained 117 polymorphic brands, using 28 primers. Oliveira et al. (2014), however, evaluated 37 Psidium accessions with 17 ISSR (Inter Simple Sequence Repeats) markers and obtained 216 polymorphic bands with an average of 13 bands per primer.

In plant breeding programs success depends on genetic variability. Therefore, it is necessary to identify it through analyses with morphological or molecular markers (Ferreira and Grattapaglia 1998). Traditionally, morphological and agronomic descriptors are used; however, these can be influenced by the environment and some can only be evaluated during the adult stage of the plants (Vieira et al. 2009). In this study, the genetic diversity analyses were performed using molecular markers because, according to Carvalho (2008), the cherry tree is a perennial species and only reaches reproductive age between six and seven years old, which would require too much time for analyses by morphological markers, particularly to evaluate the fruit. Thus, RAPD markers were used because, according to Aguiar et al. (2013), they have a low cost and can be used on any species regardless of prior knowledge of the genome, being simpler and more suitable for rapid analysis of structure and diversity in natural populations.

The similarity between accessions allowed the construction of a dendrogram, which showed the formation of four groups, with group I being comprised by two accessions ( 1 and 2), group II by three $(28,29$ and 30$)$, group III by one accession (34) and group IV by 30 accessions. The groups did not have a direct relationship with the source material, since Group I consisted of a plant collected in Venâncio Aires and another collected in Porto Alegre; group II consisted of three accessions, one collected in Porto Alegre, one in General Câmara and another in Eldorado do Sul; Group III consisted of an accession collected in São Borja; the remaining accessions are in group IV (Figure 1).

In this study, the genetic similarity of the accessions evaluated with RAPD markers was $84 \%$ (Figure 1). Similar values were obtained by Franzon et al. (2008), with $60.4 \%$ genetic similarity in Brazilian cherry tree populations with AFLP (Amplified Fragment Length Polymorphisms) markers. Salgueiro et al. (2004) also obtained $78.9 \%$ of genetic variability with AFLP markers in Brazilian cherry populations that were at least $99 \mathrm{~km}$ from each other and had no known interaction between them. Still, Margis et al. (2002) found $88 \%$ of variability within populations of this same species in the state of Rio de Janeiro. The high genetic similarity of accessions of this study (84\%) may be associated with evolutionary and natural selection factors, as well as the opening of new agricultural areas which led to the loss of many plant populations and their reproductive systems. According to Saavedra and Spoor (2002), most species had their diversity reduced as a result of plant domestication, selection and breeding. According to Borém and Miranda (2009), with the opening of new agricultural areas many genotypes were lost, often resulting in the disappearance of local varieties, causing current populations to present narrow genetic bases which can lead to genetic erosion. According to Odum (1988), these factors may compromise the continuity of the species in face of climate variations, diseases and insects or plagues. Moreover, genetic diversity is considered lower in modern cultivars and self pollinated

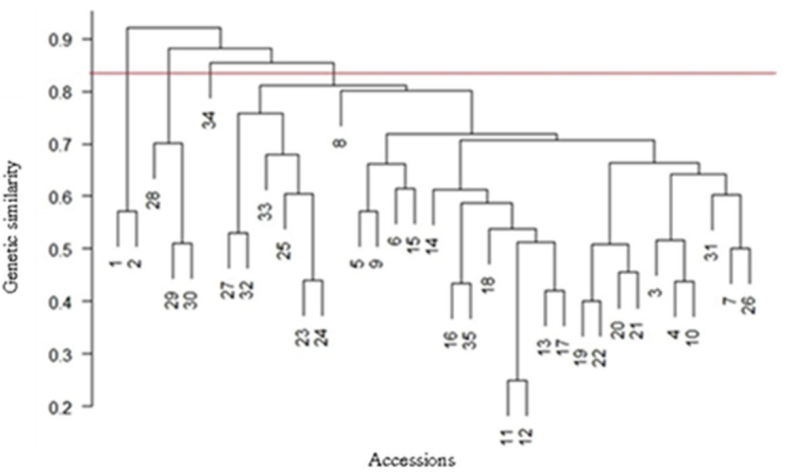

Figure 1. Dendrogram of genetic similarity between the 35 cherry accessions, obtained from RAPD markers. The dashed line indicates the $84 \%$ cut-off point based on the average similarity between populations.

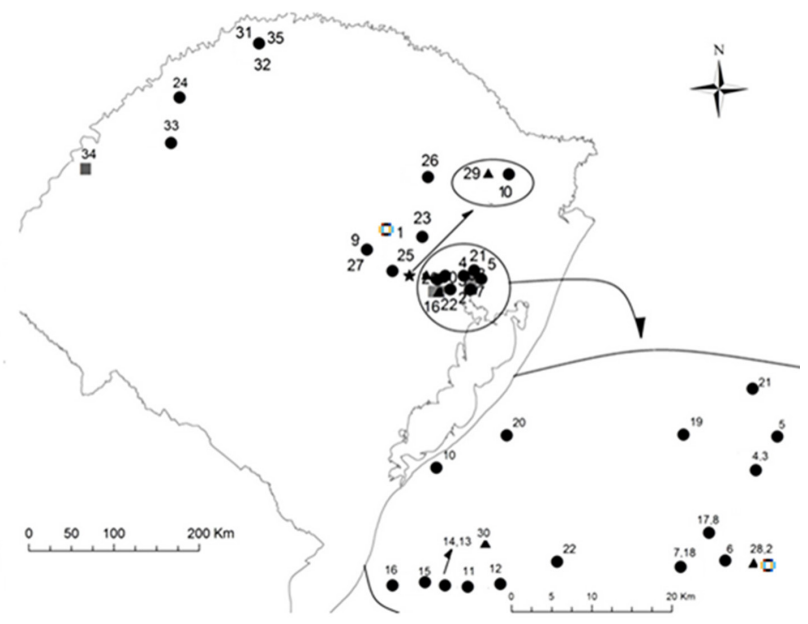

Figure 2. Collection sites of the 35 cherry accessions in the state of Rio Grande do Sul with the cluster according to genetic similarity obtained with RAPD markers. Group I = 0 ; Group II = ${ }^{\star}$; Group $\mathrm{III}= \pm$; Group IV $\bullet$ ). 
species, which would be in line with the results obtained in this study when correlated to the reproductive mode of the species since, as observed by Carvalho (2008) and Sarmento et al. (2012), the cherry tree is a self pollinated (autogamous) species and therefore this factor might explain the high similarity observed.

The distribution in groups (I, II, III and IV) according to the genetic similarity obtained with the RAPD molecular markers allowed us to observe a good distribution in the collection sites (Figure 2). These results are very significant because they will allow the selection of genotypes with greater diversity to be used as parents in directed crosses. According to Amaral Junior and Thiébaut (1999), knowledge of variability amongst materials of interest is an advantage when identifying new gene sources. Also, according to Freitas and Bered (2003), knowledge of genetic variability and maintenance of genotypes in germplasm banks is very important, as they can provide genes that confer adaptation to environmental stress and resistance to diseases and plagues. In this study, the accessions from groups I $(1,2)$, II $(28,29$ and 30$)$ and III (34) can be used as parents in crosses with plants from group IV, since they showed higher genetic diversity (Figure 1). The data corroborate with Amaral Junior and Thiébaut (1999) and Freitas and Bered (2003), whom consider that, for plant breeding, which seeks variability in the progeny with the purpose of selection of superior cultivars, the most dissimilar accessions are the most appropriate for crosses since they broaden the chances of obtaining the heterotic effect in the hybrid generation and increase the probability of recovering superior segregants in advanced generations.

In the analysis of meiotic behavior, the average of normal cells, i.e. cells with chromosomal associations in bivalents was $82.12 \%$, varying from $78.24 \%$ to $86.75 \%$. In the analysis of pollen viability, the average of normal grains was $92.44 \%$, ranging from $84.24 \%$ to $98.46 \%$. In the analysis of in vitro pollen germination, the average was $40.26 \%$, ranging from $30.45 \%$ to $44.11 \%$. In the counting of anther numbers we observed an average value of 161.85 anthers/flower, ranging from 130.54 to 185.01 anthers/flowers (Table 2). In cytological analyses, the average of cells considered normal was high in all accessions but did not differ statistically, allowing us to infer that all accessions are meiotically stable, with high pollen viability and considerable in vitro germination.

The cytological analyses in gametic cells allowed the characterization of the accessions as diploid with $n=11$, since in most cells analyzed the presence of 11 bivalents at the diakinesis stage of meiotic prophase I of was observed. By analogy, we conlude that the chromosome number of accessions is $2 n=22$ (Figure 3 ). The data collected corroborated Pedrosa et al. (1999) and Costa and Forni-Martins (2007b). In the analysis of all phases of meiosis in this study we

Table 2. Cytological analysis of 35 cherry trees accessions collected in the state of Rio Grande do Sul

\begin{tabular}{|c|c|c|c|c|c|c|c|c|c|}
\hline No. & $\begin{array}{c}\text { Cells in meiosis } \\
\text { considered nor- } \\
\text { mal (\%) }\end{array}$ & $\begin{array}{c}\text { Pollen } \\
\text { Viability } \\
(\%) \\
\end{array}$ & $\begin{array}{c}\text { Pollen } \\
\text { Germination } \\
(\%)\end{array}$ & $\begin{array}{c}\text { Average } \\
\text { No. } \\
\text { Anthers }\end{array}$ & No. & $\begin{array}{c}\text { Cells in meiosis } \\
\text { considered nor- } \\
\text { mal (\%) }\end{array}$ & $\begin{array}{c}\text { Pollen } \\
\text { Viability } \\
(\%)\end{array}$ & $\begin{array}{c}\text { Pollen } \\
\text { Germination } \\
(\%)\end{array}$ & $\begin{array}{c}\text { Average } \\
\text { No. } \\
\text { Anthers }\end{array}$ \\
\hline 1 & 80.40 & 91.54 & 40.20 & 153.82 & 19 & 85.52 & 92.58 & 41.45 & 160.09 \\
\hline 2 & 82.13 & 92.98 & 38.22 & 179.74 & 20 & 79.40 & 91.39 & 43.18 & 185.01 \\
\hline 3 & 82.10 & 90.67 & 36.34 & 150.78 & 21 & 83.25 & 87.05 & 42.22 & 173.72 \\
\hline 4 & 86.75 & 92.26 & 42.56 & 165.82 & 22 & 81.18 & 98.46 & 40.36 & 142.19 \\
\hline 5 & 81.45 & 87.86 & 34.18 & 169.31 & 23 & 82.48 & 94.81 & 41.11 & 171.58 \\
\hline 6 & 79.02 & 90.34 & 35.44 & 145.03 & 24 & 84.26 & 96.78 & 39.43 & 171.85 \\
\hline 7 & 84.36 & 93.98 & 32.08 & 160.18 & 25 & 85.42 & 89.45 & 42.77 & 163.54 \\
\hline 8 & 86.48 & 90.45 & 30.45 & 130.54 & 26 & 82.50 & 91.94 & 37.32 & 169.93 \\
\hline 9 & 82.23 & 94.06 & 42.54 & 152.92 & 27 & 80.44 & 96.63 & 42.38 & 152.81 \\
\hline 10 & 84.35 & 95.62 & 42.28 & 168.86 & 28 & 80.56 & 88.47 & 43.56 & 160.69 \\
\hline 11 & 84.12 & 90.88 & 42.26 & 136.78 & 29 & 79.12 & 97.02 & 40.44 & 163.09 \\
\hline 12 & 78.24 & 90.54 & 41.48 & 173.21 & 30 & 81.22 & 86.13 & 43.68 & 170.71 \\
\hline 13 & 80.18 & 84.24 & 43.17 & 165.54 & 31 & 83.40 & 94.17 & 43.78 & 158.16 \\
\hline 14 & 82.46 & 93.58 & 44.11 & 177.12 & 32 & 80.78 & 96.28 & 41.34 & 167.38 \\
\hline 15 & 80.78 & 93.82 & 42.03 & 177.15 & 33 & 81.58 & 95.29 & 40.62 & 162.98 \\
\hline 16 & 80.46 & 92.16 & 40.12 & 147.66 & 34 & 81.45 & 96.94 & 40.46 & 158.34 \\
\hline 17 & 81.89 & 93.25 & 38.23 & 159.87 & 35 & 80.02 & 92.06 & 40.98 & 161.92 \\
\hline \multirow[t]{2}{*}{18} & 84.18 & 91.62 & 38.17 & 156.69 & & & & & \\
\hline & & & & & Mean & $82.12^{\text {ns }}$ & $92.44^{\mathrm{ns}}$ & $40.26^{\mathrm{ns}}$ & $161.85^{\mathrm{ns}}$ \\
\hline
\end{tabular}

ns= no significant differences in average ( $5 \%$ probability) by Tukey test. 
observed few cells containing abnormalities such as laggard chromosomes, early disjunction and micronuclei (Table 2). According to Souza et al. (2000) the meiotic behavior of a plant has a direct reflection on its degree of fertility, since the occurrence of failures during the process, with lagging chromosomes or disorganized spindles represent difficulties in producing hybrids, since they produce chromosomal variation due to the loss or gain of chromosomes in new generations. Moreover, according to Muñoz et al. (2006), meiosis becomes a source of genetic variability used by organisms for environmental adaptation. The meiotic normality and therefore the high viability of pollen grains are in accordance to Muñoz et al. (2006), who claim that the normal course of meiosis ensures gamete viability. The stable meiotic behavior of accessions in this study corroborates Loguercio and Battistin (2004), who evaluated nine jambolan accessions (Syzygium cumini L.) and observed regular meiotic behavior, with the formation of 11 bivalents and pollen viability higher than $93.19 \%$. Costa and ForniMartins (2006a) evaluated the meiosis and pollen viability of four species of the Campomanesia and Psidum genus and did not observe any abnormalities and also identified a pollen viability higher than $86 \%$. Franzon and Raseira (2004) observed cytological stability higher than $96 \%$ in Acca sellowiana, while in Eugenia pyriformis and Campomanesia
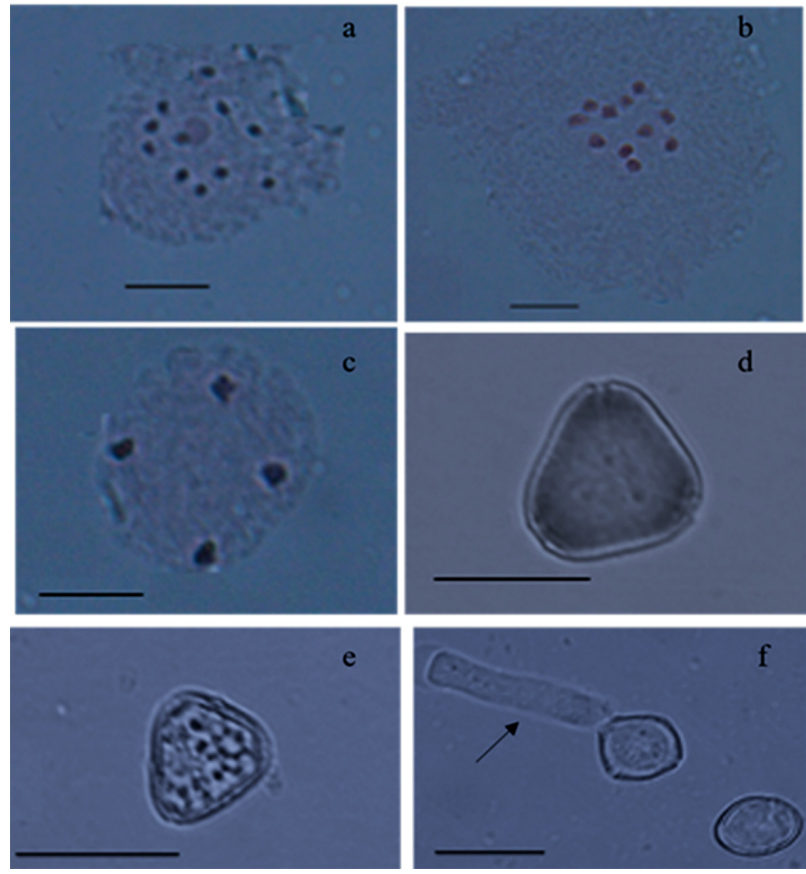

Figure 3. Cytological analysis of cherry accessions. a) Prophase I (diakinesis) with $11 \mathrm{Il}$; b) Prophase I (diakinesis) with $11 \mathrm{II}$ c) Telophase I; d) viable pollen grain; e) unviable pollen grain; f) germinated (arrow) and non-germinated pollen grain. Scale $10 \mu \mathrm{m}$. xanthocarpa the stability was $89.5 \%$ and $89.3 \%$, respectively.

The in vitro pollen germination was $40.26 \%$ (Table 2). Franzon and Raseira (2004) and Franzon et al. (2007) evaluated the germination capacity of cherry tree pollen and found values higher than $60 \%$. These results may be associated with the methodology since, according to Marcellán and Camadro (1996), many factors can influence germination, such as: culture medium, incubation temperature and length. Franzon et al. (2007) include others, such as flower development stage when collecting and storing the pollen.

When counting anther numbers we observed an average value of 161.85 anthers/flowers, but with a variation of 130.54 to 179.74 anthers/flower (Table 2). There was a considerable variation although the factor or factors responsible for this variation cannot be identified.

\section{CONCLUSIONS}

The accessions evaluated show high polymorphism, genetic similarity and cytological stability and can be used directly in commercial orchards, and also as male parents in directed crosses in breeding programs.

\section{REFERENCES}

Aguiar RV, Cansian RL, Kubiak GB, Slaviero LB, Tomazoni TA, Budke JC and Mossi AJ (2013) Variabilidade genética de Eugenia uniflora L. em remanescentes florestais em diferentes estádios sucessionais. Revista Ceres 60: 226-233.

Amaral Júnior AT and Thiébaut JTL (1999) Análise multivariada na avaliação da diversidade em recursos genéticos vegetais. Editora Universidade Estadual do Norte Fluminense - UENF, Rio de Janeiro, $55 p$.
Borém A and Miranda G (2009) Melhoramento de Plantas. Editora UFV, Viçosa, 523p.

Carvalho PE (2008) Espécies arbóreas brasileiras. Editora Colombo, Brasília, 593p.

Costa IR and Forni-Martins ER (2006a) Chromosome studies in Brazilian species of Campomanesia Ruiz \& Pavon and Psidium (Myrtaceae Juss.). Caryologia 59: 7-13.

Costa IR and Forni-Martins ER (2006b) Chromosome studies in species of Eugenia, Myrciaria and Plinia (Myrtaceae) from south-eastern Brazil. Australian Journal of Botany 54: 409-415. 
Costa IR and Forni-Martins ER (2007) Karyotype analysis in South American species of Myrtaceae. Botanical Journal of the Linnean Society 155: $571-580$

Donadio LC, Môro FV and Servidone AA (2004) Frutas brasileiras. Editora Novos Talentos, Jaboticabal, 288p.

Ferreira ME and Grattapaglia D (1998) Introdução ao uso de marcadores moleculares em análise genética. Editora Embrapa, Brasília, 220p.

Franzon RC, Gonçalves RS, Antunes LEC, Raseira MCB and Trevisan R (2008) Propagação da pitangueira através da enxertia de garfagem. Revista Brasileira de Fruticultura 30: 488-491.

Franzon RC and Raseira MCB (2004) Meiotic index in Myrtaceae native fruits trees from southern Brazil. Crop Breeding and Applied Biotechnology 4: 344-349.

Franzon RC, Raseira MCB and Wagner JA (2007) Testes de germinação in vitro e armazenamento de pólen de pitangueira (Eugenia uniflora L.). Acta Scientiarum-Agronomy 29: 251-255.

Freitas LB and Bered F (2003) Genética e evolução vegetal. Editora UFRGS, Porto Alegre, $463 p$.

Gomes Filho A, Oliveira JG, Viana AP, Siqueira APO, Oliveira MG and Pereira MG (2010) Marcadores moleculares RAPD e descritores morfológicos na avaliação da diversidade genética de goiabeiras (Psidium guajava L.). Acta Scientiarum-Agronomy 32: 627-633.

Guerra D, Schifino-Wittmann MT, Schwarz SF, Souza PVD and Campos SS (2013) Influence of greenhouse versus field conditions on reproductive characteristics of citrus rootstocks. Crop Breeding and Applied Biotechnology 13: 186-193.

Guerra D, Schifino-Wittmann MT, Schwarz SF, Weiler RL, Dahmer N and Souza PVD (2016) Tetrapolidization in citrus rootstocks: effect of genetic constitution and environment in chromosome duplication. Crop Breeding and Applied Biotechnology 16: 35-41.

Landrum LR and Kawasaki ML (1997) The Genera of Myrtaceae in Brazil: an Illustrated Synoptic Treatment and Identification Keys. Brittonia 49: 508-536.

Loguercio AP and Battistin A (2004) Microsporogênese de nove acessos de Syzygium cumini (L.) Myrtaceae oriundos do Rio Grande do SulBrasil. Revista da FZVA 11: p.95-106.

Lorenzi H (2002) Árvores Brasileiras: Manual de identificação e cultivo de plantas arbóreas nativas do Brasil. Editora Nova Odessa, São Paulo, 368p.

Marcellán ON and Camadro EL (1996) The viability of asparagus pollen after storage at low temperatures. Scientia Horticulturae 67: 101104.

Margis R, Felix D and Caldas JF (2002) Genetic differentiation among three neighboring Brazil-cherry (Eugenia uniflora L.) populations within the Brazilian Atlantic rain forest. Biodiversity and Conservation 11: 149-163.

Muñoz AM, Caetano CM, Vallejo FA and Sanchez MS (2006)
Comportamiento meiótico y descripción morfológica del pólen de pronto alivio. Acta Agronomica 1: 1-9.

Odum EP (1988) Ecologia. Editora Guanabara, Rio de Janeiro, 434p.

Oliveira F (2007) Aspectos da vegetação arbórea encontrada na orla da Praia da Alegria no município de Guaíba, RS, Brasil. Caderno de Pesquisa 19: 6-17.

Oliveira MSP, Amorim EP, Santos JB and Ferreira DF (2007) Diversidade genética entre acessos de açaizeiro baseada em marcadores RAPD. Ciência e Agrotecnologia 31: 1645-1653.

Oliveira NNS, Viana AP, Quintal SSR, Paiva CL and Marinho CS (2014) Análise de distância genética entre acessos do gênero Psidium via marcadores ISSR. Revista Brasileira de Fruticultura 36: 917-923.

Pedrosa A, Gataí J, Barros AE, Felix L and Guerra M (1999) Citogenética de angiospermas coletadas em Pernambuco. Acta Botânica Brasílica 13: 49-51.

Pillar VD (1999) Howsharp are classifications? Ecology 80: 2508-2516.

Rodrigues VEG and Carvalho DA (2001) Levantamento etnobotânico de plantas medicinais no domínio do cerrado na região do Alto Rio Grande, Minas Gerais. Ciência e Agrotecnologia 25: 102-123.

Romagnolo MB and Souza MC (2004) Os gêneros Calycorectes O. Berg, Hexachlamys O. Berg, Myrcianthes O. Berg, Myrciaria O. Berg e Plinia L. (Myrtaceae) na planície alagável do alto rio Paraná, Brasil. Acta Botânica Brasilica 18: 613-627.

Saavedra G and Spoor W (2002) Genetic base broadening in autogamouscrops: Lycopersion esculentum Mill. As a model. Managing Plant Genetic Diversity 443: 292-299.

Sahar N and Spiegel-Roy P (1984) In vitro germination of avocado pollen. Scientia Horticulturae 19: 886-888.

Salgueiro F, Felix D, Caldas JF, Margis-Pinheiro M and Margis R (2004) Even populations differentiations for maternal and biparental gene markers in Eugenia uniflora, a widely distributed species from the Braziliam coastal Atlantic rain forest. Diversity and Distributions 10: 201-210.

Sarmento MB, Silva ACS and Silva CS (2012) Recursos genéticos de frutas nativas da família Myrtaceae no Sul do Brasil. Magistra 24: 250-262.

Simioni C and Valle CB (2011) Meiotic analysis in induced tetraploids of Brachiaria decumbens Stapf. Crop Breeding and Applied Biotechnology 11: 43-49.

Souza MM, Pereira TNS, Rodrigues R, Dutras GA and Sudré CP (2000) Irregularidades meióticas em pimenta. Horticultura Brasileira 18: 748-749.

Vieira ESN, Pinho EVRV, Carvalho MGG and Da Silva PA (2009) Caracterização de cultivares de soja por descritores morfológicos e marcadores bioquímicos de proteínas e isoenzimas. Revista Brasileira de Sementes 1: 086-094.

Wunch A and Hormaza JI (2007) Characterization of variability and genetic similarity of European pear using microsatellite loci developed in apple. Scientia Horticulturae 113: 37-43. 